\title{
高層建築物の火災時崩壊挙動に関する数值解析的検証 VERIFICATION ON COLLAPSE BEHAVIORS OF HIGH-RISE BUILDINGS UNDER FIRE USING NUMERICAL APPROACH
}

\author{
磯部大吾郎*, レティタイタン** \\ Daigoro ISOBE and Thi Thai Thanh LE
}

\begin{abstract}
Fire-induced collapse behaviors of a high-rise building with an outrigger truss system were verified using the ASI-Gauss technique. The effects of fire patterns and structural parameters on the redundant strengths were surveyed by observing the collapse initiation time: the duration from the beginning of the fire until collapse initiation. From the numerical results, it is confirmed that collapse initiation times are significantly affected by the member joint strengths if the axial force ratio is small on the condition that the fire pattern is nearly symmetrical, and the load paths to and from the outrigger truss system are sufficiently protected.
\end{abstract}

\author{
Keywords : High-rise buildings, Collapse behavior, Collapse initiation time, Redundant \\ strength, Outrigger truss system, ASI-Gauss technique \\ 高層建築物，崩壊挙動，崩壊開始時間，余剩強度，アウトリガートラスシステム，ASI-Gauss 法
}

\section{1. はじめに}

高層建築物の火災を引き起こす要因や火災規模は様々であり，そ の際の建築物に残存する余剩強度について系統的に議論するのは極 めて困難である。9.11 事件でのニューヨーク世界貿易センター (WTC) ビルのように, 飛行機が衝突した際にジェット燃料が拡散 して大規模火災が発生し，それが主要因となって 1 時間〜 1 時間半 程で完全に倒壊してしまった事例が存在する。その一方では, 2005 年にマドリッドの Windsor ビルで起きた大火災のように, ビルが全 焼したにも関わらず骨組だけは残存し，丸一日経ても全体崩壊には 至らなかった事例もある。このような大規模かつ複雑な現象が絡み 合う問題では, 様々な構造パラメータを操作しその余剩強度に対す る寄与の度合いを検証することで，建築物の火災崩落防止対策を図 る上で有用な知見が得られるものと思われる。その構造パラメータ としては, 具体的には軸力比, 接合部強度, アウトリガートラスシ ステムの部材強度, 火災範囲などが挙げられる。例えば, 米国の研 究調査機関 FEMA と NIST が 9.11 事件についてまとめた報告書 1) 2) によると, 風外力に対する補強システムとして WTC ビルの上層階 に設置されたアウトリガートラスシステムが，その崩壊開始までの 時間を稼ぐ点で有効であった可能性が示唆されている。チューブ構 造上部にアウトリガートラスシステムが設置されたことで応力伝達 経路が増して余剩強度が確保され, 火災時に応力再配分が適切に行 われ，崩落開始までの時間が延びたことは十分に考えられる。また 同報告書では，WTC1 と WTC2 とで航空機の衝突箇所および火災 範囲が異なったことが，それぞれの崩壊開始までの時間の差異につ
ながったとしている。福田らによる研究 3)では, 飛行機衝突後の両ビ ルの応力再配分状況が数值解析によって明らかにされ，上記報告を裏 付ける検証結果が得られている。WTC の構造的崩壊要因を特定し, 高層建築物の火災崩落防止対策を進める上でも, 様々な構造パラメ ータの余剩強度への寄与について知ることは重要な課題であり，さ らなる検証が必要と思われる。

そこで本稿では, ASI-Gauss 法 4) に基づく解析手法に建築物の崩 落挙動をリアルに表現できる新たなアルゴリズムを導入し, 30 層 7 スパンのチューブ骨組構造モデルに大規模火災が発生した場合に, その火災範囲，軸力比，接合部強度およびアウトリガートラスシス テムの部材強度が建物の余剩強度や崩壊挙動に及ぼす影響について 数值解析を通じて検証した。本稿では，火災発生から崩壊開始まで の時間を崩壊開始時間と定義し，これを建物が有する余剩強度の目 安として扱うこととした。検証の結果, 火災範囲および様々な構造 パラメータが建物の崩壊開始時間に与える影響について知見が得ら れたので，ここに報告する。続く第 2 章では数值解析手法の概要に ついて記し，第 3 章では解析モデルと解析条件，第 4 章では解析結 果と考察を示し，第 5 章に結論を述べる。

\section{2. 数值解析手法}

数值解析には, 大規模骨組構造の構造解析において最小限のコス トで精度の高い解析が可能である, ASI-Gauss 法 4）を基に独自開発 した有限要素解析コードを使用した。ASI-Gauss 法は, 要素内の数 值積分点を部材性状に合わせて順応的にシフトすることで，計算コ
* 筑波大学大学院 准教授・博士 (工学)

** 筑波大学 大学院生
Assoc. Prof., Dept. of Engineering Mechanics and Energy, Univ. of Tsukuba, Dr. Eng. Graduate Student, Univ. of Tsukuba 
ストを低く抑えることが可能な順応型 Shifted Integration 法 (ASI 法）5）をさらに改良したものである。その具体的な改良点は，2つ の線形チモシェンコはり要素をサブセット要素として考え, 弾性範 囲ではそのガウス積分点に相当する位置に応力評価点を配置するよ うに数值積分点をシフトすることで, 弾性変位解の精度を向上させ た点である。また, ASI 法と同様に部材内の軸方向に沿った断面力 分布を計算し, 数值積分点のシフトと同時に断面力を解放すること で特定の箇所に破断面を表現できる点が大きな特長である。さらに 部材が破断した後には, 幾何学的な位置関係に基づいて接触を判定 し，要素間をギャップ要素で拘束することで接触を表現している。

ASI-Gauss 法の解析コードに関する詳細については他文献 4) に譲 り, 本稿では火災崩落解析を行う上で必要なアルゴリズムを中心に 記すこととする。

部材の降伏条件としては, 柱の曲げ塑性耐力に対する強度比を陽 に表す接合部強度係数 $C_{M}(0.0 \sim 1.0)$ を定義し, これを取り入れた以 下の条件式を用いた。

$$
f=\left(\frac{M_{x}}{C_{M} M_{x 0}}\right)^{2}+\left(\frac{M_{y}}{C_{M} M_{y 0}}\right)^{2}+\left(\frac{N}{N_{0}}\right)^{2}-1=f_{y}-1=0
$$

ここで, $f_{y}$ は降伏関数, $M_{x}, M_{y}$ は $x, y$ 軸回りの曲げモーメント, $N$ は軸力である。下添え字”””, 各断面力成分が単独で部材断面に作 用した場合の全断面塑性值であることを示す。ASI-Gauss 法では 1 本の部材を 2 つの線形チモシェンコはり要素で表現するため, 部材 中央側の節点では $C_{M}=1.0$, 部材端側の節点では $C_{M} \leqq 1.0$ の接合部 強度係数を設定し，降伏判定を行う。

次に, 部材破断の判定条件としては, 部材を構成する各要素の曲 率，引張軸ひずみおよびせん断ひずみによる次式を用いた。

$$
\left|\frac{\kappa_{x}}{\kappa_{x 0}}\right| \geq 1 \quad \text { or } \quad\left|\frac{\kappa_{y}}{\kappa_{y 0}}\right| \geq 1 \quad \text { or } \quad \frac{\varepsilon_{z}}{\varepsilon_{z 0}} \geq 1 \quad \text { or } \quad\left|\frac{\gamma_{x z}}{\gamma_{x z}}\right| \geq 1 \quad \text { or } \quad\left|\frac{\gamma_{y z}}{\gamma_{y z 0}}\right| \geq 1
$$

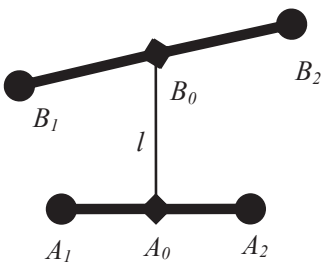

図 1 要素の中点間距離 $l$

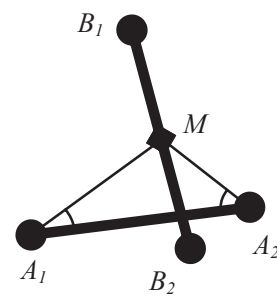

(a)要素の位置関係その 1

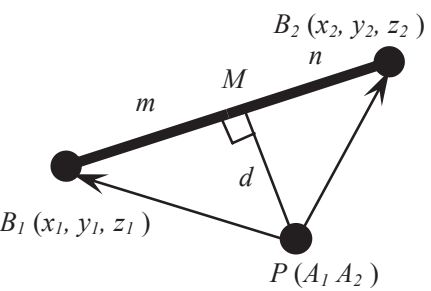

図 2 接触要素 $A_{1} A_{2}$ と被接触 要素 $B_{1} B_{2}$ 間の最短距離 $d$

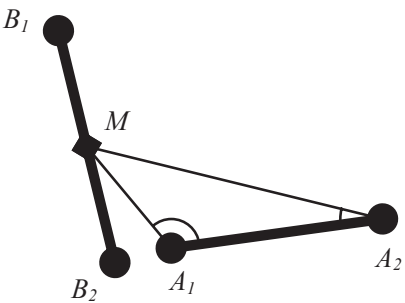

(b)要素の位置関係その 2

図 3 要素の位置関係による接触判定
ここで, $\kappa_{x}, \kappa_{y}, \varepsilon_{z}, \gamma_{x z}, \gamma_{y z}$ はそれぞれ要素における $x$ 軸, $y$ 軸回りの 曲率, 引張軸ひずみ, $x$ 軸, $y$ 軸方向のせん断ひずみであり, 下添え 字”””は破断臨界值であることを示す。これらの破断臨界值は，例え ばボルト締めされた継手の曲げ試験 6) や引張試験 7) などの結果か ら入手できるため，信頼性の高い判定を行うことが可能である。後 の解析には, 破断臨界值として $\kappa_{x 0}=\kappa_{y 0}=3.333 \times 10^{-4}, \gamma_{x z 0}=\gamma_{y z 0}=$ $1.300 \times 10^{-2}, \varepsilon_{z 0}=0.17$ の值を用いた。

接触判定には, 以下に示す内分ベクトル型接触アルゴリズムを用 い，接近する $2 つ の$ 要素の節点間距離および節点の幾何学的位置関 係により判定を行った。例えば, 図 1 に示す 2 つのはり要素（線分 $A_{1} A_{2}$ : 接触要素, 線分 $B_{1} B_{2}$ : 被接触要素) の接触判定を行う際には, まずそれぞれの要素の中点間距離 $l$ と $2 つ$ 要素の平均長 $l$ 'を計算 する。そして, $l<l$ 'となったとき, 接触要素の近傍に被接触要素の 候補が存在するとみなし, 図 2 に示寸ように被接触要素に接触要素 を投影する。その際, 線分 $A_{1} A_{2}$ と線分 $B_{1} B_{2}$ との最短距離 $d$ をとる 内分点 $M\left(\mathrm{~B}_{1} \mathrm{M}\right.$ と $\mathrm{B}_{2} \mathrm{M}$ の内分比 $\left.m: n\right)$ の座標值 $\left(x_{M}, y_{M}, z_{M}\right)$ を次式に より求める。

$$
\left(x_{M}, y_{M}, z_{M}\right)=\frac{n\left(x_{1}, y_{1}, z_{1}\right)+m\left(x_{2}, y_{2}, z_{2}\right)}{m+n}
$$

ここで， $\left(x_{1}, y_{1}, z_{1}\right)$ および $\left(x_{2}, y_{2}, z_{2}\right)$ はそれぞれ節点 $B_{1}, B_{2}$ の座標 值である。次に, 両要素の平均部材幅よりも $d$ の值が小さくなった 場合, 図 3 に示寸接触要素 $A_{1} A_{2}$ の 2 節点 $A_{1}, A_{2}$ と被接触要素 $B_{1} B_{2}$ の内分点 $M$ の 3 点からなる三角形を考え, その 3 辺の長さから次の 条件式を使って $\angle M A_{1} A_{2}$ および $\angle M A_{2} A_{1}$ が鋭角か否かを調べる。

$$
\begin{aligned}
& {\overline{A_{1} M}}^{2} \leq{\overline{A_{2} M}}^{2}+{\overline{A_{1} A_{2}}}^{2} \\
& {\overline{A_{2} M}}^{2} \leq{\overline{A_{1} M}}^{2}+{\overline{A_{1} A_{2}}}^{2}
\end{aligned}
$$

式(4)，(5)がどちらも満たされた場合，図 3(a) のように $\angle M A_{1} A_{2}$ お よび $\angle M A_{2} A_{1}$ はどちらも鋭角となるため， 2 つの要素は接触してい るものと判定する。どちらか一方の条件が満たされない場合, 図 3(b) のようにどちらか一方の角が鈍角となるため, 2 つの要素は接触し ないとみなし, 接触判定から除外寸る。 2 つの要素が接触判定され た場合，図 4 に示寸ように節点間に計 4 つのギャップ要素（接合要 素）を設けて拘束する。ギャップ要素は近接する他の要素と同じ材

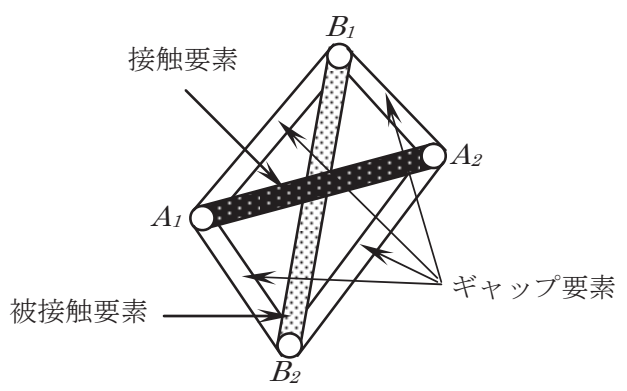

図 4 ギャップ要素による接触の表現 


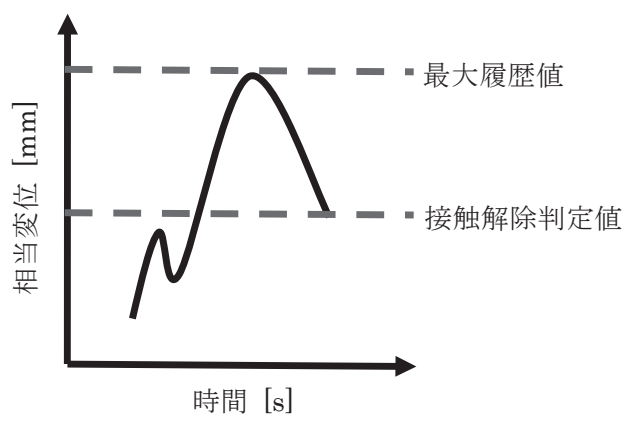

図 5 接触解除の概念図

料性状（ただし弾性）および断面形状を持つと仮定した。

次に, 接触後に部材が離反する挙動を表現するため, 接触時から 要素端の節点に生じる変位量を監視し, その量がある条件を満たし た際に接触を解除するアルゴリズムを導入した。このアルゴリズム には, ギャップ要素を削除する処理, および再び同じ組の要素の接 触を表現する処理が含まれる。まず，ギャップ要素によって拘束さ れている計 4 つの節点の接触開始ステップから現ステップまでの変 位量を用い，次式に従って相当変位 $|u|$ を計算する。

$$
|u|=\sum_{i=1}^{4}\left\{\sqrt{\left(u_{X i}+\Delta u_{X i}\right)^{2}+\left(u_{Y i}+\Delta u_{Y i}\right)^{2}+\left(u_{Z i}+\Delta u_{Z i}\right)^{2}}\right\}
$$

ここで, $u_{X i}, u_{Y i}, u_{Z i}$ は関連する節点のうち, $i$ 番目の節点の接触開 始から前ステップまでのそれぞれ全体座標系 $X, Y, Z$ 方向の変位, $\Delta$ は現ステップでの増分を示す。図 5 に示すように, $|u|$ がその最大 履歴值のある割合以下になったとき，接触を解除することとする。 このときの割合を接触解除判定比と定義する。また, 接触力が弱い 際に判定が過度に繰り返されることを回避するため, $|u|$ の最大履歴 值が一定の值以下では接触が解除されないように下限值を設定した。 他方, 接触解除後に要素間距離が十分に離れないうちに接触判定を 行うと, 同じ要素間で再び接触が判定されてしまう可能性がある。 これでは跳数返りを表現できないため, 接触解除後一定時間は接触 しないように接触回避時間を設けた。接触解除判定比と下限值, 接 触回避時間を適切に設定すると, 適切な位置で要素間の接触が解除 され, 互いに接触要素の候補として再び内分ベクトル型接触アルゴ リズムを通ることになる。この操作により何度でも接触と離反が繰 り返され, 部材の跳衫返りや重なりなどが表現可能となった。なお, 本稿で行った解析の接触解除判定比, 下限值と接触回避時間には, 事前に簡単な部材実験を行い, その結果と照らし合わせてそれぞれ $0.2,0.1 \mathrm{~mm}, 0.1 \mathrm{~s}$ という值を用いた。

部材の温度上昇時刻歴には, 図 6 に示寸 JIS A 1304 の耐火曲線を 線形近似したものを用い，特定の時間で火災の一般的な温度である $700^{\circ} \mathrm{C}$ まで線形的に上昇するものと仮定した。温度上昇に伴う鋼材 の耐力低下曲線として, 図 7 の NIST 2) によるものがある。これは, 鋼材に耐火被覆を施さない場合のもので， $700^{\circ} \mathrm{C}$ 近辺において弾性 係数は常温時の約 $60 \%$, 降伏応力は約 $10 \%$ まで低下寸るというもの である。飛行機が衝突して耐火被覆が剥がれたとされるWTC の事 例に倣い，解析には図 7 の曲線を使用することにした。また，温度

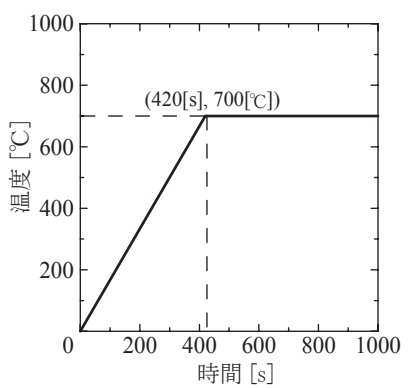

図 6 温度上昇曲線

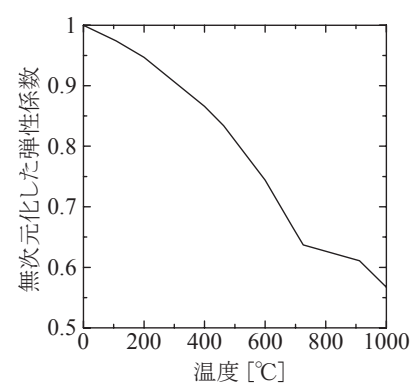

(a) 弾性係数

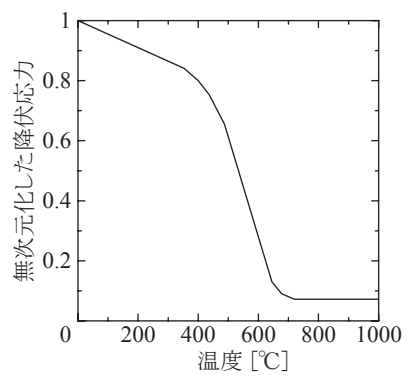

（b）降伏応力
図 7 温度上昇に伴う鋼材の耐力低下曲線

上昇に伴う鋼材の熱膨張は，次式に示す熱ひずみを加えることによ り考慮した。

$$
\Delta \varepsilon_{T}=\alpha \Delta T
$$

ここで, $\Delta \varepsilon_{T}, \Delta T$ および $\alpha$ はそれぞれ, 熱ひず夕増分, 温度増分, 線膨張係数である。また，機械ひずみと熱ひずみの関係は次式のよ うに表される。

$$
\varepsilon_{m}=\varepsilon-\varepsilon_{T}
$$

ここで， $\varepsilon_{m}, \varepsilon_{T}$ および $\varepsilon$ はそれぞれ機械ひずみ，熱ひずみ，全体ひ ずみである。

火災崩落現象は, 大別すると崩壊前の準静的領域と崩壊が始まっ てからの動的領域に分けられる。そこで，崩壊前の準静的領域では 比較的粗い時間増分で，崩壊開始が判定されてからは小さい時間増 分に切り替えて運動方程式を解くように設定した。具体的には, 初 期の時間増分を $1.0 \mathrm{~s}$ とし，1ステップ当りの変位増分が部材の断 面寸法よりも大きい要素が出た場合に崩壊が開始したと判定し，時 間増分を $1.0 \mathrm{~ms}$ に変更して解析する。運動方程式の時間積分には 陰解法を用い，計算の不安定化を招く高周波振動を抑えるため，数 值減衰を考慮して Newmark の $\beta$ 法の積分パラメータを $\beta=4 / 9$, $\delta=5 / 6^{8)}$ とした。ソルバーには共役傾斜法 (CG 法), 非線形増分理 論には updated Lagrangian formulation を用いた。

\section{3. モデルと解析条件}

解析対象として, 図 8 に示すような 30 層 7 スパンのチューブ構 造を線形チモシェンコはり要素でモデル化した。床や壁はモデル化 せず, 柱や梁等の線材のみで構成している。その総要素数は 9,360 , 総節点数は 6,644 , 総自由度数は 39,600 である。30 階のコアフレ 


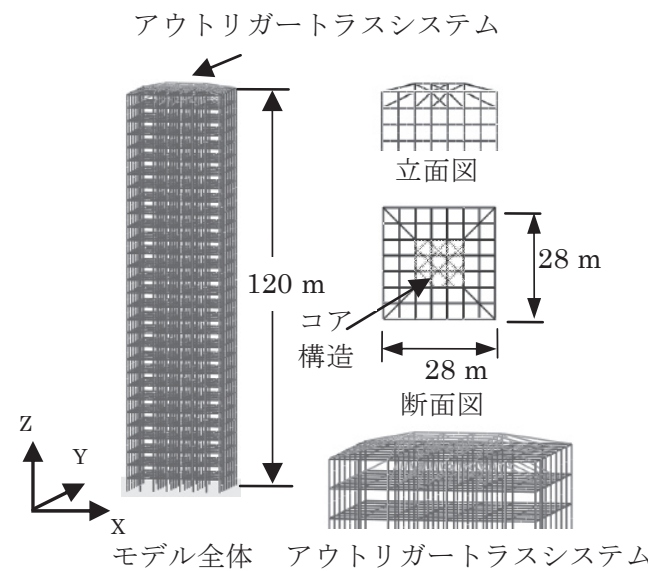

図 8 モデルの概要
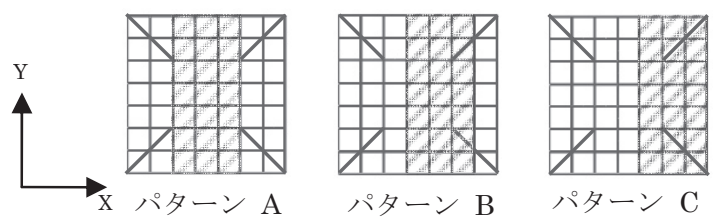

図 9 火災範囲 $(21$ 階 24 階 $)$

一ムにブレースを取り付け, 上層階にアウトリガートラスシステム を配置した。これは, 架構の剛性を高め, 転倒モーメントに対抗し, 外周部をコア部で吊り上げることを想定したシステムである。部材 には SN490 の鋼材を用い, 弾性係数, 降伏応力, ポアソン比, 密 度をそれぞれ $214 \mathrm{GPa}, 325 \mathrm{MPa} ， 0.3 ， 7.9 \times 10^{-6} \mathrm{~kg} / \mathrm{mm}^{3}$ とした。 部材断面寸法は， 1 層部分の柱を $\mathrm{BOX}$ 鋼 $\square-700 \times 28$, はりを $\mathrm{H}-700 \times 300 \times 13 \times 24$ とし，これらの太さを上層方向へ 5 層ごとに段 階的に細くした。部材断面寸法值は固定し, 床荷重のみを変化させ て軸力比を設定した。

構築したモデルに対し, 火災範囲, 最下層柱の軸力比, 接合部強 度係数 $C_{M}$, アウトリガートラス部材強度比の 4 つのパラメータを変 化させて解析を行う。まず火災範囲の影響を調べるため，モデルの 21 階〜24 階の部分で図 9 に示すような 3 種類の範囲に火災が発生 したものと仮定し, 該当する箇所の要素を全て図 6 に従って温度上 昇させた。次に, 軸力比を $0.1 \sim 0.5$ の範囲で変化させ, 接合部強度
係数 $C_{M}$ を 0.1 ～ 0.6 の範囲で変化させた。また，アウトリガートラ スシステムの有無およびその部材強度の相違による影響を調べるた めに，最下層部のはり材に対するアウトリガートラス部材の強度比 を 0.25 から 2.0 まで段階的に変化させた。火災発生時刻から建物が 崩壊を開始する時刻までの時間（崩壊開始時間）を解析結果より求 め，上記のパラメータとの関連性を調心゙た。なお，それぞれのケー スでの解析時間はおよそ 8 時間 (CPU: $2.93 \mathrm{GHz}$ Xeon) であった。

\section{4. 解析結果}

設計用床荷重を変えてモデルの強度を変化させた際の，最下層柱 の軸力比と崩壊開始時間との関係を図 10 に示す。ただし，この場 合にはアウトリガートラス部材強度比を 1 としてある。まず, どの 火災パターンにおいても軸力比が増すと崩壊開始時間が次第に短く なっていることが分かる。また，軸力比が高い領域（概ね 0.25 以上） では，どの火災パターンに対してもアウトリガートラスシステムの 効果は見られないが，軸力比が低い領域では崩壊開始時間に相違が 見られ，アウトリガートラスシステムがその懸垂能力を発揮して建 物全体の余剰強度を増加させていることが確認できる。そこで，そ れぞれの領域の軸力比 0.33 (設計用床荷重 $10.0 \mathrm{kN} / \mathrm{m}^{2}$ ) および 0.19

(設計用床荷重 $5.0 \mathrm{kN} / \mathrm{m}^{2}$ ) の場合について，接合部強度係数およ びアウトリガートラスの部材強度比が崩壊開始時間に対して与える 影響について調査した。軸力比 0.33 の場合の結果を図 11 に, 軸力 比 0.19 の場合の結果を図 12 に示す。ただし，設定解析時間（2000 s）内にモデルが崩壊を開始しない場合には, 図にデータをプロット していない。軸力比が 0.33 の場合（図 11）には，火災パターン A およびBにおいて接合部強度が高い場合に崩壊開始時間が若干遅く なる効果が見られるが，火災パターンＣの非対称火災の場合には， $C_{M}=0.1$ の場合を除き, 接合部強度の大小によらず約 $450 \mathrm{~s}$ の一定の 崩壊開始時間を示している。アウトリガートラスの部材強度比によ っても崩壊開始時間があまり変化しないことが分かる。一方，軸力 比が 0.19 の場合（図 12）では，アウトリガートラスシステムの存 在は確かに大きな効果を生んでいるが，その部材強度比によって崩 壊開始時間はあまり変化せず，むしろ接合部強度の大小によって崩 壊開始時間が大きく変化していることが分かる。例えば火災パター ン $\mathrm{B}$ の場合には， $C_{M}=0.2$ ではアウトリガートラスシステムが存在 することで $40 \mathrm{~s}$ 程度しか崩壊開始時間は遅延しないが， $C_{M}=0.3$ で

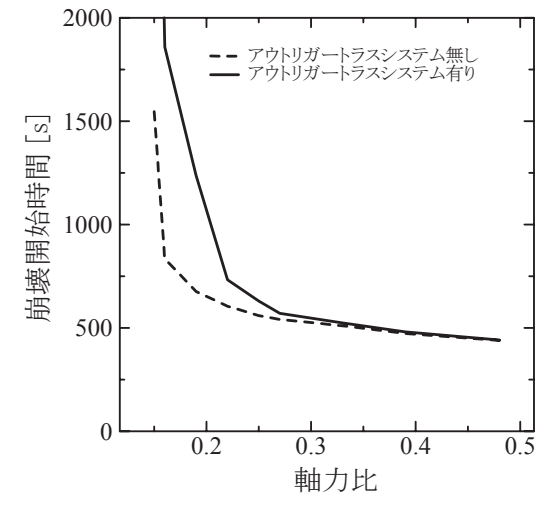

(a) パターン A

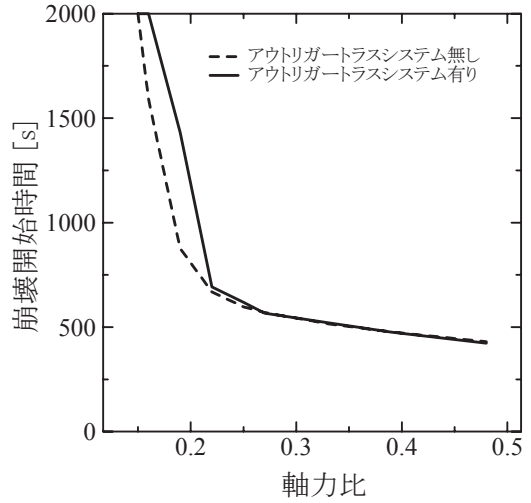

(b) パターン B

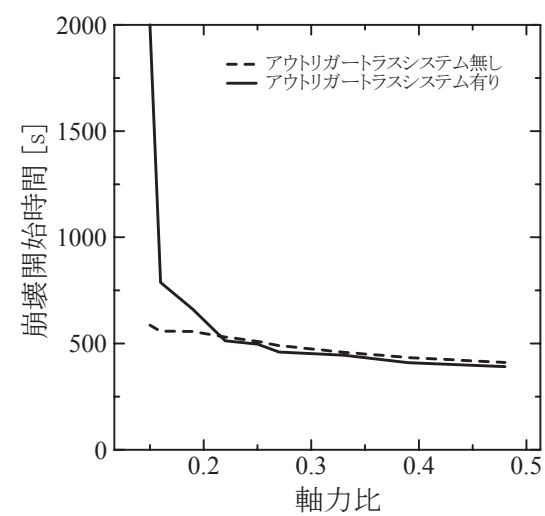

(c) パターン C

図 10 軸力比による崩壊開始時間の相違 


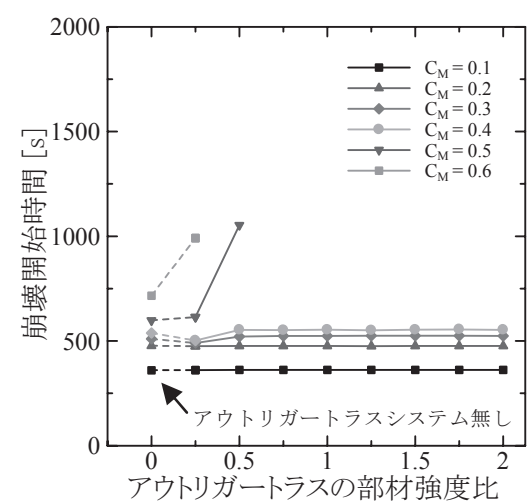

(a) パターン A

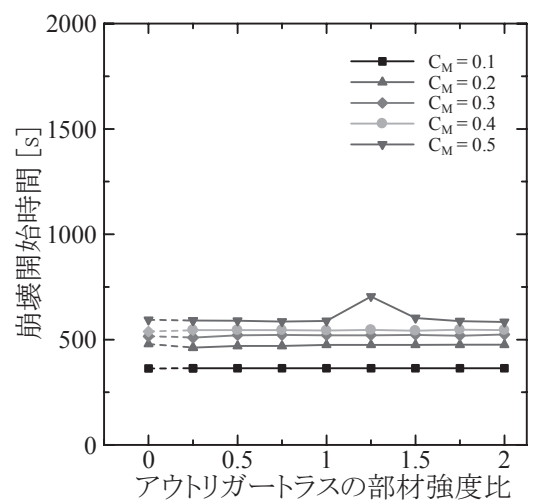

(b) パターン B

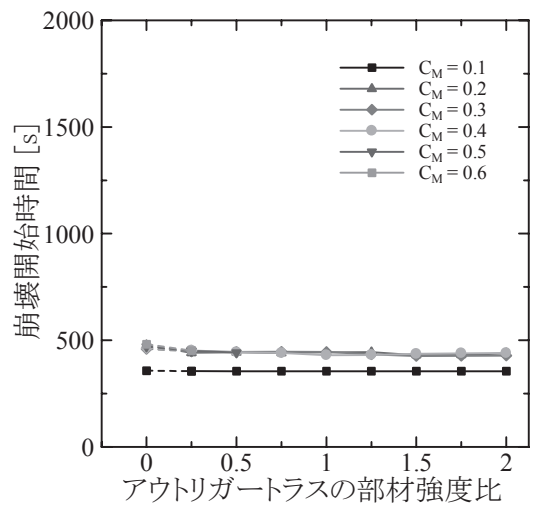

(c) パターン C

図 11 接合部強度係数およびアウトリガートラス部材強度比による崩壊開始時間の相違（軸力比=0.33）

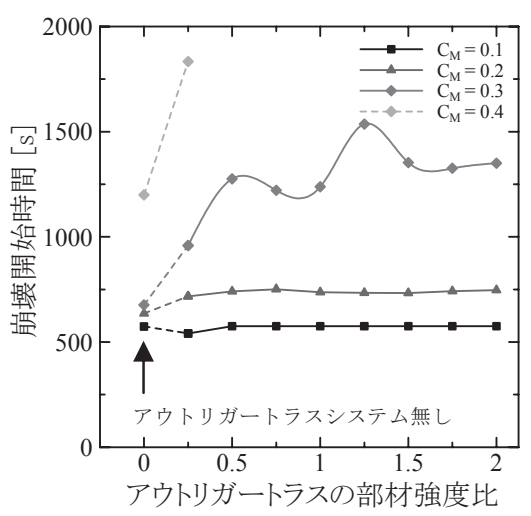

(a) パターン A

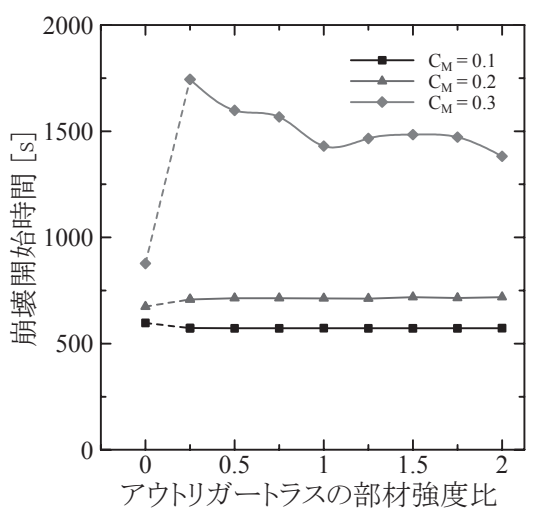

(b) パターン B

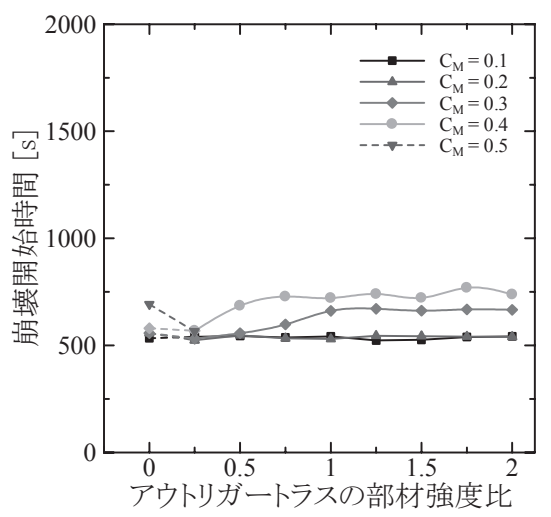

(c) パターン $\mathrm{C}$

図 12 接合部強度係数およびアウトリガートラス部材強度比による崩壊開始時間の相違（軸力比=0.19）

は約 $520 \mathrm{~s}$ 以上の遅延効果が見られる。火災パターン $\mathrm{C}$ の場合には, 構造強度の変化による崩壊開始時間の変化はやはり少ない。

次に, 最下層柱の軸力比 $0.33, C_{M}=0.3$, 部材強度比を 1 とした アウトリガートラスシステムが配置されたモデルに対し, 図 9 のそ れぞれの範囲で火災が発生した場合に対する建物の崩壊挙動を調心 た。図 13 の概略図に示すように, どの火災パターンの場合にも温 度上昇に伴い柱部材が耐力低下を起こし, 崩壊初期の段階では座屈 および部材端での破断が併発される現象が見られた。崩壊挙動を図 14 に示す。いずれも全体崩壊は免れず, また， $C_{M}$ の值が小さくな るにつれ崩壊が早まることから, 温度が上昇した際の耐力低下の影 響と共に，接合部強度の脆弱性が崩壊を招いていることが予想でき る。全体的な挙動はどのケースも概称変わらないが，初期の上層部 の傾角と崩壊開始時間には相違が見られる。特に, 火災範囲がパタ ーン $\mathrm{C}$ の場合には他の場合と比べて 1 分程度崩壊開始が早まってお り, 火災の非対称性が崩壊を早める要因の一つであることが確認で きる。また, それぞれの火災範囲内にある要素を取り除き, 最上層 階に鉛直下向きに一様な荷重を静的に加えていくプッシュダウン解 析を行った結果, 崩壊が開始される際の降伏限界荷重はパターン $\mathrm{A}$, B，C それぞれの場合で $381 \mathrm{kN} ， 591 \mathrm{kN} ， 80 \mathrm{kN}$ であった。パタ ーン A に比べて比較的非対称性の強いパターン B の方が高い降伏限 界荷重を示寸のは, パターン B の場合にはコア構造が火災範囲に完 全に覆われておらず, アウトリガートラスシステムを含めた上層部 の懸垂能力が比較的高かったためである。外力や解析条件の相違か ら単純に降伏限界荷重と崩壊開始時間の関連について議論するのは
困難だが，図 14 でパターン B の場合に崩壊開始時間が早まってい ないのは，上記のような理由があるためと考えられる。

さらに, 最下層柱の軸力比を 0.19 とし, 他の条件は図 14 のもの と同等としたモデルに対し，図 9 のそれぞれの範囲で火災が発生し た場合についての崩壊挙動を図 15 に示す。図 14 のモデルに対し構 造強度に比較的余裕があるために, どの火災パターンの場合にも崩 壊開始時間が延びているが，その延び幅は火災パターン C の場合は あまり大きくない。全体的な挙動はどのケースも図 14 と概初変わ らないが，火災パターン A の場合には最後まで真直に崩落せず，途 中から上層部の傾角が大きくなっていることが分かる。これは，建 物の軸力比が低く, 床荷重に比してコア構造の強度が高いため, 下 層部が上層部の落下に対し比較的大きな抵抗力を発揮したためと考 えられる。また，いずれの軸力比，いずれの火災パターンの場合に も崩壊開始から $20 \mathrm{~s}$ 前後で全体崩壊に至っており, その崩壊に要す る時間には大きな差異がなかった。

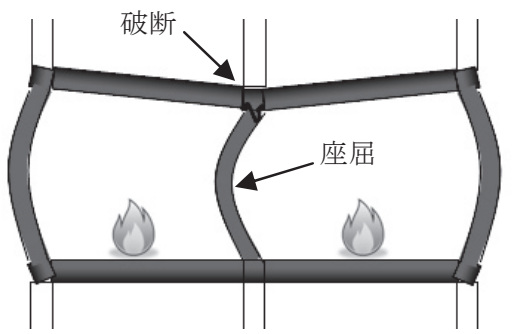

図 13 崩壊初期の挙動 


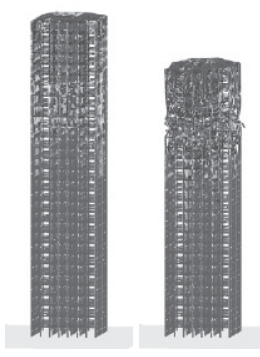

$500.0 \mathrm{~s} \quad 527.5 \mathrm{~s}$

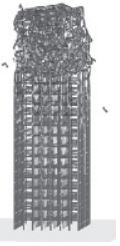

$529.5 \mathrm{~s}$

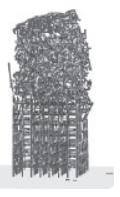

$537.0 \mathrm{~s}$

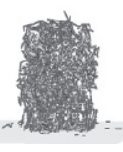

$550.0 \mathrm{~s}$
図 14 (a) 建物の崩壊挙動（軸力比 $=0.33, C_{M}=0.3$, パターン $\mathrm{A}$ )

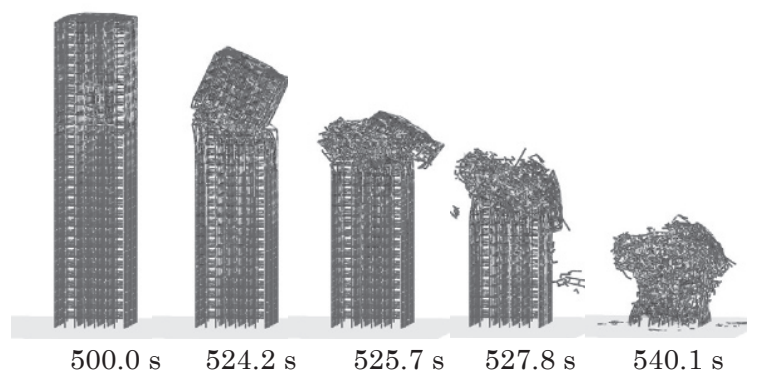

図 14 (b) 建物の崩壊挙動（軸力比 $=0.33, C_{M}=0.3$, パターン $\mathrm{B}$ )

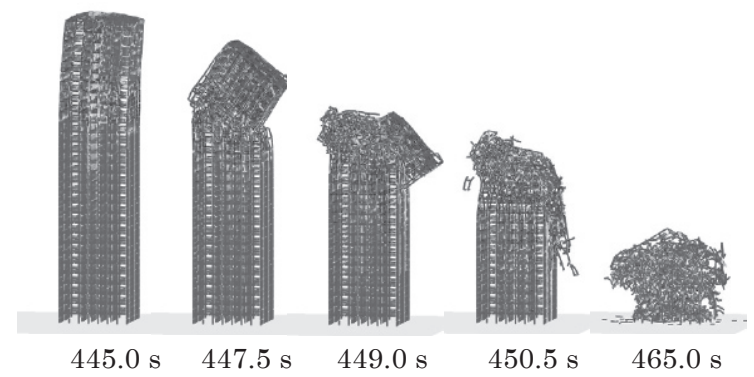

図 14 (c) 建物の崩壊挙動（軸力比 $=0.33, C_{M}=0.3$, パターン $\mathrm{C}$ )

以上の結果より, 崩壊開始時間は特に軸力比が低い場合に接合部 強度による影響を大きく受けること，ただしそれは火災範囲がある 程度対称性を保ち，アウトリガートラスシステムを含む建物全体の 応力伝達経路が確保されている場合に限る, ということが確認され た。外周構造の片面が全面的に耐力低下寸る火災パターン $\mathrm{C}$ の場合 には, アウトリガートラスシステムの懸垂能力が早く限界を超える ため, 軸力比の大小に関係なく, 接合部強度やアウトリガートラス の部材強度比の増加によって崩壊開始時間が大幅に遅延される効果 は見られなかった。

\section{5. 最後に}

本稿では, 30 層 7 スパンのチューブ骨組構造を対象に火災崩落解 析を行い, 様々な構造パラメータが崩壊開始時間に与える影響につ いて数值解析的に検証を行った。その結果, 応力伝達経路が十分に 確保されるようなパターンの火災が発生した場合において，アウト リガートラスシステムがその効果を発揮し, モデル全体の余剰強度 が増すことが定性的に示された。この傾向は, 軸力比が低く, 接合 部強度係数が高いモデルでは特に顕著であった。またこのことは, 9.11 事件で比較的対称な火災範囲を負った WTC 1 が，比較的非対 称な火災範囲を負った WTC 2 よりも崩壊開始までの時間が長かっ

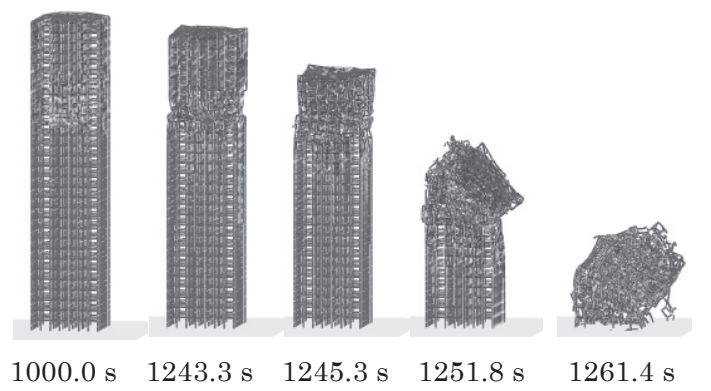

図 15 (a) 建物の崩壊挙動（軸力比 $=0.19, C_{M}=0.3$, パターン A)

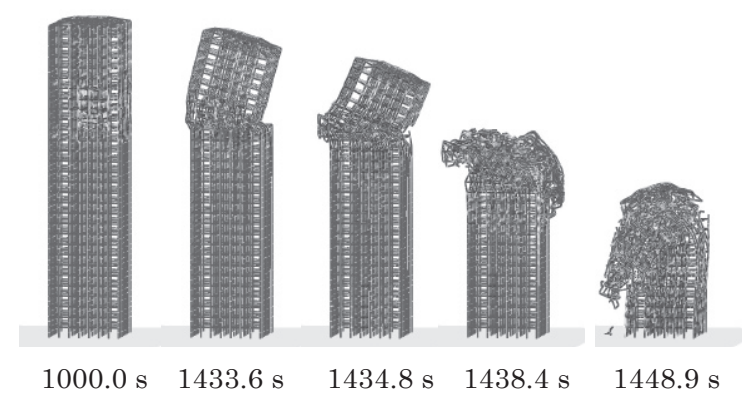

図 15 (b) 建物の崩壊挙動 (軸力比 $=0.19, C_{M}=0.3$, パターン $\mathrm{B}$ )

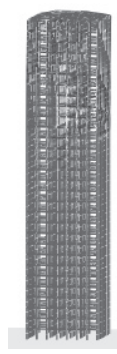

$500.0 \mathrm{~s}$

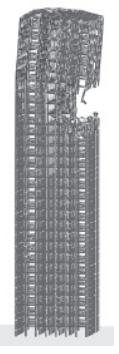

$665.3 \mathrm{~s}$

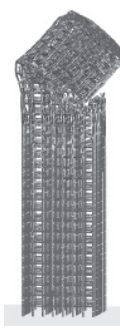

$669.3 \mathrm{~s}$

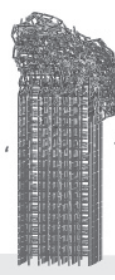

$671.8 \mathrm{~s}$

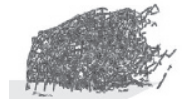

$687.8 \mathrm{~s}$
図 15 (c) 建物の崩壊挙動（軸力比 $=0.19, C_{M}=0.3$, パターン C)

たことを説明できるものである。今後は, WTC 全体モデルに対し， 飛行機衝突から火災崩落までの連続的な挙動解析を行う予定である。

\section{参考文献}

1) ASCE/FEMA: World Trade Center Building Performance Study: Data Collection, Preliminary Observation and Recommendations, 2002.

2) NIST NCSTAR 1: Federal Building and Fire Safety Investigation of the World Trade Center Disaster: Final Report on the Collapse of the World Trade Center Towers, National Institute of Standards and Technology (NIST), 2005.

3）福田 隆介, 福澤 栄治, 小鹿 紀英, 森川 博司: ニューヨーク世界貿易セ ンタービルの航空機衝突時の全体応答と局部損傷の評価, 日本建築学会構 造系論文集，第 570 号, pp.77-84, 2003.8 .

4) 磯部大吾郎, チョウミョウリン: 飛行機の衝突に伴う骨組鋼 構造の崩壊解析, 日本建築学会構造系論文集, 第5 79 号, pp.39-46, 2004.5 .

5) Y. Toi and D. Isobe: Adaptively Shifted Integration Technique for Finite Element Collapse Analysis of Framed Structures. Int. J. Numer. Methods Eng., Vol. 36, pp.2323-2339, 1993.

6) 平島 岳夫, 濱田 直之, 尾崎 文宣, 安部 武雄, 上杉 英樹: 高温時におけ る高力ボルトの剪断変形性状に関する実験的研究, 日本建築学会構造系論 文集，第 621 号, pp.175-180, 2007.11.

7）日本建築学会：鋼構造接合部設計指針, 2001 。

8) K. J. Bathe: Finite Element Procedures, Prentice Hall, 1996. 